\title{
TRANSFER TO THE MOUSE OVIDUCT OF EGGS WITH AND WITHOUT THE ZONA PELLUCIDA
}

\author{
R. A. BRONSON* AND ANNE MaLAREN† \\ Institute of Animal Genetics, Edinburgh University
}

(Received 19th September 1969)

\begin{abstract}
Summary. When pre-implantation embryos were transferred to the oviducts of pseudopregnant recipient females, on the 1st day post coitum, the percentage of females becoming pregnant was greater when a very small inoculum volume was used. The number of eggs injected per oviduct, in the range from two to ten, did not significantly affect the percentage developing into foetuses. The pregnancy rate was lower for onecell than for two-cell and eight-cell eggs, morulae and blastocysts, but the percentage of eggs developing into live foetuses in those females which became pregnant was similar for all stages.

Blastocysts transferred to the oviducts of recipients on the first day p.c. passed down the oviduct at a rate similar to that of the recipients' own unfertilized eggs.

Removal of the zona pellucida with pronase prevented almost entirely the development of eight-cell eggs to foetuses after transfer to oviducts of recipients on the 1st day p.c., although development in vitro was not affected. Removal of the zona did not reduce the proportion of blastocysts developing successfully, after transfer to either oviduct or uterus. It was concluded that the zona pellucida is necessary for the transit of cleavage stages through the oviduct in normal pregnancy.

The rate of transmigration between uterine horns following transfer to the oviduct was very low $(0.4 \%)$.
\end{abstract}

\section{INTRODUCTION}

In 1959, Tarkowski demonstrated that two-cell eggs could develop successfully after transfer to the oviducts of pseudopregnant recipient mice. Of the transferred embryos, $70 \%$ survived to birth, or to autopsy between the 15 th and 19 th day of pregnancy. This success rate was greater than that of any other method of egg transfer in mice. Whether the method would prove satisfactory for the transfer of eggs at other stages of development was not fully answered. A lower proportion of blastocysts than of two-cell eggs developed into live foetuses after transfer to the oviduct, and Tarkowski therefore speculated that the shock

\footnotetext{
* Present address: Department of Surgery, New York University Medical Center, 550 First Avenue, New York, N.Y. 10016.

$\dagger$ Agricultural Research Council Unit of Animal Genetics.
} 
caused to the blastocysts by the act of transfer might weaken their capacity for implantation in the uterus. A similar finding was reported by Noyes \& Dickmann (1961) for the rat.

The present experiments were designed to explore the effect of the stage of eggs transferred, and to determine whether an intact zona pellucida is required for normal development in vivo.

\section{MATERIALS AND METHODS}

The mice used were from the randomly bred $Q$ strain. One-cell eggs were recovered in phosphate buffered saline (PBS) from donors on the 1st day post coitum (p.c.), by incising the ampulla of the oviduct, and then treated with hyaluronidase (Sigma, Type 1, $350 \mathrm{NF}$ units/mg) to remove the cumulus oophorus. The hyaluronidase solution was made up at a concentration of $0.5 \%$ in PBS containing $10 \mathrm{mg} / \mathrm{ml}$ of polyvinyl pyrrolidone, added to reduce the stickiness of the eggs. The time required to disperse the cumulus, at room temperature, was 3 to $5 \mathrm{~min}$. The treated eggs were then washed in three changes of $1 \mathrm{ml}$ PBS.

Two-cell eggs were obtained on the morning of the 2 nd day p.c. by flushing the excised oviduct with PBS. Eight-cell eggs were expressed by blunt dissection from the uterine end of the oviduct on the 3rd day p.c., and morulae and blastocysts were flushed from the uterine horns on the 4th day p.c. (vaginal plug found on 1st day p.c.).

The zona pellucida was removed from the eggs with pronase (Calbiochem, B grade, 45,000 PUK units/g), at a concentration of $0.5 \%$ (Mintz, 1962). This solution was made up in PBS containing $10 \mathrm{mg} / \mathrm{ml}$ of polyvinyl pyrrolidone, incubated at $37^{\circ} \mathrm{C}$ for $2 \mathrm{hr}$, and dialysed overnight in the cold $\left(4^{\circ} \mathrm{C}\right)$ against PBS (Mintz, 1967). Eggs were treated with pronase solution at room temperature and observed under the dissecting microscope. They were removed from the pronase either when the zona had just vanished ( 8 to $12 \mathrm{~min}$ ) (Treatment 1 ) or when a faint ring of zona still remained $(7$ to $11 \mathrm{~min}$ ) (Treatment 2). This remnant of zona had dissolved by the time of transfer. After removal from the pronase, the eggs were carried through two washings with $1 \mathrm{ml}$ of PBS each, and placed in transfer medium $10 \%$ calf serum in PBS, Calf Serum No. 1, natural clot, heated, Wellcome Labs.).

Transfers were carried out according to a modification of the method of Tarkowski $(1959,1970)$. On the lst day p.c., recipient mice mated to vasectomized males were anaesthetized with intraperitoneal Nembutal $(0.0125 \mathrm{ml} / \mathrm{g}$ body weight of $6 \mathrm{mg} / \mathrm{ml}$ solution). A transverse, dorsal skin incision was made to the left of the midline. The left ovary could usually be seen through the posterior abdominal wall, which was then incised. The ovarian fat pad was grasped with smooth forceps and pulled through the wound, carrying the ovary, oviduct and uterine horn with it. The distal end of the mesentery of the uterus was also incised to aid in ease of retraction. A small arterial bull-dog clamp, grasping the ovarian fat pad and lying across the dorsum of the mouse, provided the correct amount of traction. The remainder of the operation was carried out under the dissecting microscope, at $\times 28$ magnification. A strong point-source of 
illumination was used. By careful observation of the tubo-ovarian junction, the infundibulum of the oviduct could be located within the ovarian bursa as the ovary was rotated. A transverse incision was then made in the bursa with iridectomy scissors. The edges of the bursa were retracted with fine pointed forceps, and then the funnel-shaped opening of the infundibulum could usually be observed directly. A fine tungsten wire needle was helpful at times to locate the ostium of the infundibulum.

Before the operation, the eggs to be transferred were taken up into a finely drawn Pasteur pipette by capillary action. The tip of the pipette was placed into the infundibulum and passed into the oviduct as far as possible, usually to the first bend. The fluid containing the eggs was then injected with a hand bulb. An approximate estimate by weight of the minimum volume of fluid used for transfer was $0 \cdot 1$ to $0.4 \mu \mathrm{l}$. In contrast to transfers carried out to the uterus (McLaren \& Michie, 1956), the introduction of a small amount of air into the oviduct was not detrimental to the success of the transfer operation. In fact, the air served as a useful marker that the entire inoculum had been injected.

In all cases, unless otherwise noted, the transfers were carried out into the left oviduct. The right side served as a control that the vasectomized males were indeed consistently sterile. Autopsies were performed after the 10th day p.c. Pregnant mice are defined as those recipients possessing at least one live foetus at the time of autopsy. A small number of decidua (i.e. moles) were observed, but these have not been included in any of the analyses since they do not necessarily indicate the presence of an embryo. Only four recipient uteri were found at autopsy to contain decidua in the absence of live foetuses.

Blastocysts were transferred to the uterus of recipients on the 3rd day according to the method of McLaren \& Michie (1956). Eggs were cultivated in vitro according to the method of Brinster (1963).

\section{RESULTS}

The success of the transfer operations depended critically upon the volume injected into the oviduct (Table 1). A six-fold reduction in the volume of the inoculum increased the pregnancy rate from $25 \%$ to $63 \%\left(\chi_{(1)}^{2}=5 \cdot 7, P<0.02\right)$. The increase in the number of live foetuses in those recipients which became pregnant was not statistically significant. In subsequent experiments, the smaller volume was used.

The stage of development of the transferred eggs (Table 2) also had a significant effect upon the pregnancy rate (heterogeneity $\chi_{(3)}^{2}=8.3, P<0.05$ ). This is accounted for by the lower proportion of pregnancies among females receiving one-cell eggs $\left(\chi_{(1)}^{2}=7 \cdot 61, P<0.01\right.$, for the comparison between one-cell eggs and the rest). In those females which became pregnant, however, the survival of the transferred eggs was unrelated to their stage of development.

Because of the lower pregnancy rate after transfer of one-cell eggs, it was necessary to examine the effect of the number of eggs injected for one-cell and later stages separately. When small numbers of eggs are injected, some females will fail to become pregnant not through reproductive failure or factors causing loss of the inoculum as a whole, but because none of the eggs survives the various 
hazards to which eggs are subject as individuals. Somewhat lower pregnancy rates will, therefore, be expected after the injection of smaller numbers of eggs, but the success rate in those females which become pregnant will be correspondingly higher. However, with survival rates of the order found in the present study this effect will be small. In fact (Table 3), the number of eggs injected had no significant effect either on the pregnancy rate or on the percentage of eggs transferred to pregnant females and subsequently recovered as live foetuses.

TABLE 1

THE EFFECT OF VOLUME INJECTED ON SUCCESS RATE OF TRANSFERS OF ONE- OR TWO-CELL EGGS TO THE OVIDUCTS OF REGIPIENTS ON THE 1ST DAY POST COITUM

\begin{tabular}{|c|c|c|c|c|}
\hline \multirow{2}{*}{$\begin{array}{l}\text { Size of } \\
\text { inoculum* }\end{array}$} & \multirow{2}{*}{$\begin{array}{l}\text { No. of } \\
\text { recipients }\end{array}$} & \multirow{2}{*}{$\stackrel{\%}{\text { pregnant }}$} & \multicolumn{2}{|c|}{ Pregnant recipients } \\
\hline & & & $\begin{array}{l}\text { No. of eggs } \\
\text { transferred }\end{array}$ & $\begin{array}{l}\% \text { live } \\
\text { foetuses }\end{array}$ \\
\hline $\begin{array}{l}\text { Large } \\
\text { Small }\end{array}$ & $\begin{array}{l}12 \\
66\end{array}$ & $\begin{array}{l}25 \\
63\end{array}$ & $\begin{array}{r}12 \\
139\end{array}$ & $\begin{array}{l}58 \\
71\end{array}$ \\
\hline
\end{tabular}

* The relative size of the inoculum in the two groups was determined by weight to be $6: 1$.

TABLE 2

THE EFFECT OF STAGE OF DEVELOPMENT OF EGGS TRANSFERRED TO THE OVIDUCTS OF REGIPIENTS ON THE IST DAY p.c.

\begin{tabular}{|c|c|c|c|c|}
\hline \multirow{2}{*}{$\begin{array}{c}\text { Developmental } \\
\text { stage }\end{array}$} & \multirow{2}{*}{$\begin{array}{l}\text { No. of } \\
\text { recipients }\end{array}$} & \multirow{2}{*}{$\begin{array}{c}\% \\
\text { pregnant }\end{array}$} & \multicolumn{2}{|c|}{ Pregnant recipients } \\
\hline & & & $\begin{array}{l}\text { No. of eggs } \\
\text { transferred }\end{array}$ & $\begin{array}{l}\% \text { live } \\
\text { foetuses }\end{array}$ \\
\hline \multirow{2}{*}{$\begin{array}{l}\text { One-cell } \\
\text { Two-cell } \\
\text { Eight-cell } \\
\text { Morulae and } \\
\text { blastocysts }\end{array}$} & $\begin{array}{l}60 \\
19 \\
10\end{array}$ & $\begin{array}{l}53 \cdot 3 \\
73 \cdot 7 \\
90 \cdot 0\end{array}$ & $\begin{array}{r}110 \\
68 \\
36\end{array}$ & $\begin{array}{l}75 \cdot 5 \\
73 \cdot 5 \\
69 \cdot 4\end{array}$ \\
\hline & 15 & $73 \cdot 3$ & 63 & $66 \cdot 7$ \\
\hline
\end{tabular}

The pregnancy rate with one-cell eggs was consistently lower however many eggs were injected.

To determine the effect of removing the zona pellucida, eight-cell eggs were treated with pronase before transfer to the oviduct. As described in the Methods section, two exposure times for pronase treatment were used. Very few eggs developed successfully on transfer to the oviduct after either treatment (Table 4). The viability of the eggs removed from the pronase before lysis was complete (Treatment 2) was independently checked by in vitro culture, and was found not to differ from that of control eggs, with the zona intact (Table 4).

When blastocysts were treated with pronase to remove the zona, a different picture was seen (Table 5). If the zona was allowed to lyse completely in the pronase solution (Treatment 1), no development occurred; but after the less harsh treatment, the success rate after transfer to either the oviduct or uterus 
was not significantly below that of blastocysts with the zona intact. Evidently the degree of exposure to pronase was critical.

To confirm that normal development after removal of the zona and subsequent transfer to the oviduct was possible at the blastocyst but not at the eightcell stage, a further small experiment was carried out (Table 6). The difference was in the expected direction and statistically highly significant.

TABLE 3

THE EFFEGT OF NUMBER OF EGGS TRANSFERRED TO THE OVIDUCTS OF RECIPIENTS ON THE IST DAY POST COITUM

\begin{tabular}{c|c|c|c|c|c|c}
\hline \multirow{2}{*}{$\begin{array}{c}\text { No. of eggs } \\
\text { transferred }\end{array}$} & \multicolumn{3}{|c|}{ One-cell eggs } & \multicolumn{3}{c}{ Other stages } \\
\cline { 2 - 7 } & $\begin{array}{c}\text { No. of } \\
\text { recipients }\end{array}$ & $\begin{array}{c}\% \\
\text { pregnant }\end{array}$ & $\begin{array}{c}\% \text { success } \\
\text { rate in } \\
\text { pregnant } \\
\text { females }\end{array}$ & $\begin{array}{c}\text { No. of } \\
\text { recipients }\end{array}$ & $\begin{array}{c}\% \\
\text { pregnant }\end{array}$ & $\begin{array}{c}\% \text { success } \\
\text { rate in } \\
\text { pregnant } \\
\text { females }\end{array}$ \\
\hline 2 & 16 & $56 \cdot 3$ & $83 \cdot 3$ & 4 & $75 \cdot 0$ & $66 \cdot 7$ \\
3 & 19 & 47.4 & $70 \cdot 4$ & 7 & $71 \cdot 4$ & $73 \cdot 3$ \\
4 & 18 & $55 \cdot 6$ & $72 \cdot 5$ & 14 & $64 \cdot 3$ & $61 \cdot 1$ \\
5 & 6 & $50 \cdot 0$ & $80 \cdot 0$ & 5 & $100 \cdot 0$ & 72.0 \\
6 & 0 & - & - & 6 & $83 \cdot 3$ & 80.0 \\
7 & 0 & - & - & 6 & $83 \cdot 3$ & $62 \cdot 9$ \\
10 & 1 & $100 \cdot 0$ & $80 \cdot 0$ & 2 & $100 \cdot 0$ & $80 \cdot 0$ \\
\hline
\end{tabular}

TABLE 4

THE EFFECT OF REMOVING THE ZONA WITH PRONASE ON THE SUCCESSFUL DEVELOPMENT OF EIGHT-CELL EGGS in vivo AND in vitro

\begin{tabular}{l|c|c|c}
\hline \multicolumn{1}{c|}{ Category } & $\begin{array}{c}\text { No. of } \\
\text { recipients }\end{array}$ & $\begin{array}{c}\text { No. of } \\
\text { eggs }\end{array}$ & $\begin{array}{c}\text { \%o of eggs developing to live } \\
\text { foetuses (in vivo) or blasto- } \\
\text { cysts (in vitro) }\end{array}$ \\
\hline $\begin{array}{l}\text { Pronase treatment 1, } \\
\text { transferred to oviducts }\end{array}$ & 23 & 92 & 3 \\
$\begin{array}{l}\text { Pronase treatment 2, } \\
\text { transferred to oviducts* }\end{array}$ & 6 & 21 & 0 \\
$\begin{array}{l}\text { Pronase treatment 2, } \\
\text { cultured in vitro* }\end{array}$ & - & 27 & 84 \\
$\begin{array}{l}\text { Eggs placed directly in } \\
\text { culture with zona intact* }\end{array}$ & - & 23 & 88 \\
\hline
\end{tabular}

* Eight-cell eggs from each donor mouse were divided into three groups. One group was treated with pronase to remove the zona and then transferred to recipients on the lst day p.c.; the other two groups were cultured, with or without the zona.

Some histological observations were made, after fixation of oviducts in formol saline, sectioning at $8 \mu$ and staining with haematoxylin and eosin. Five oviducts were examined within an hour of transfer of two-cell eggs (pseudopregnant recipients, $\frac{1}{2}$ day p.c.). Transferred eggs were observed in all, near or even adherent to the clump of cumulus cells surrounding the native one-cell eggs, or occasionally nearer the infundibular end of the ampulla. No transferred eggs were found beyond the cumulus. At $1 \frac{1}{2}$ days p.c., six oviducts of pregnant females showed two-cell eggs in the upper part of the isthmus, grouped fairly close 
together. At the same stage of pseudopregnancy, after the introduction of blastocysts with or without the zona pellucida $24 \mathrm{hr}$ previously, one-cell unfertilized eggs were observed in approximately the same region of the isthmus, with blastocysts nearby. Blastocysts were seen in five out of six and five out of seven oviducts, respectively, after transfer of control and zona-free eggs; in the

TABLE 5

THE EFFEGT OF REMOVING THE ZONA WITH PRONASE ON THE SUCCESSFUL DEVELOPMENT OF BLASTOGYSTS AFTER TRANSFER TO THE OVIDUGT OR UTERUS

\begin{tabular}{|c|c|c|c|c|}
\hline Category & $\begin{array}{l}\text { No. of } \\
\text { recipients }\end{array}$ & $\underset{\text { pregnant }}{\text { No. }}$ & $\begin{array}{l}\text { Total no. of } \\
\text { blastocysts } \\
\text { transferred }\end{array}$ & $\begin{array}{l}\text { No. of } \\
\text { foetuses }\end{array}$ \\
\hline $\begin{array}{l}\text { Pronase treatment } 1 \text {, } \\
\text { transferred to oviducts }\end{array}$ & 8 & 0 & 25 & 0 \\
\hline $\begin{array}{l}\text { Pronase treatment } 2, \\
\text { transferred to oviducts* }\end{array}$ & 6 & 3 & 17 & 6 \\
\hline $\begin{array}{l}\text { Pronase treatment } 2, \\
\text { transferred to one } \\
\text { horn of uterus* }\end{array}$ & 6 & 3 & 24 & 6 \\
\hline $\begin{array}{l}\text { Blastocysts with zona intact, } \\
\text { transferred to opposite horn of } \\
\text { uterus* }\end{array}$ & 0 & 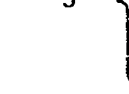 & 19 & 6 \\
\hline
\end{tabular}

* Blastocysts from each donor mouse were divided into three groups. One group was treated with pronase to remove the zona pellucida and transferred to the oviducts of recipients on the lst day p.c. One group was treated with pronase to remove the zona and transferred to the left uterine horn of recipients on the 3rd day p.c. The remaining group was not treated with pronase, but transferred directly to the right uterine horn of the same recipients (3rd day p.c.). One recipient received zona-free blastocysts into both uterine horns, in error.

TABLE 6

THE EFFECT OF STAGE OF DEVELOPMENT OF ZONA-FREE EGGS ON SUCCESS RATE OF TRANSFERS TO THE OVIDUCT

\begin{tabular}{l|cc|cc}
\hline $\begin{array}{c}\text { Siage of } \\
\text { development of } \\
\text { zona-free eggs }\end{array}$ & $\begin{array}{c}\text { No. of } \\
\text { recipients }\end{array}$ & $\begin{array}{c}\text { No. } \\
\text { pregnant }\end{array}$ & $\begin{array}{c}\text { No. of eggs } \\
\text { transferred } \\
\text { (total) }\end{array}$ & $\begin{array}{c}\text { No. of } \\
\text { live } \\
\text { foetuses }\end{array}$ \\
\hline Eight-cell & 4 & 1 & 29 & 1 \\
Blastocyst & 4 & 3 & 28 & 14 \\
\hline
\end{tabular}

successful transfers, the recovery rates were twelve out of twenty-four and fourteen out of twenty-six blastocysts, respectively. Of the twelve blastocysts observed in the control group, one was still surrounded by a zona and one was half-way out; the remaining ten had shed the zona. Five empty zonae were also seen, although the stain used was not optimal for identification of the zona.

\section{DISGUSSION}

In the present work, the pregnancy rate among females receiving transfers of one-cell eggs to the oviduct was significantly lower than when two-cell or later 
stages were transferred. The non-pregnant females were evenly distributed with respect to clutches of one-cell eggs from individual donors (heterogeneity $\left.\chi^{2}{ }_{(8)}=5 \cdot 7\right)$; hence the lower pregnancy rate is more likely to be due to a higher rate of transfer failure than to failure of fertilization, or greater sensitivity to adverse conditions, on the part of whole clutches. In those females which became pregnant, the percentage of eggs developing into live foetuses was as high for one-cell as for later stages.

Apart from the lower pregnancy rate with one-cell eggs, the percentage of eggs developing into live foetuses was similar for all stages tested, even for blastocysts removed from the uterus near the time of implantation. This finding is in contrast to that of Tarkowski (1959). Examination of the excised oviducts $24 \mathrm{hr}$ following transfer revealed that the mobility of the transferred blastocysts did not differ from that of the one-cell, unfertilized eggs of the pseudopregnant host. The blastocysts appeared morphologically normal. The shedding of the zona pellucida by blastocysts retained in the oviduct, with persistence of the empty zonae, has been reported previously by Orsini \& McLaren (1967).

Of 263 live foetuses found at autopsy, all but one were in the uterine horn corresponding to the injected oviduct. This low rate of transmigration between horns is consistent with the finding of Runner (1951), that one out of eighty embryos examined had migrated to the opposite horn following transfer of one-cell eggs to the ovarian capsule. It suggests that the significantly higher rate (four out of forty-six) reported by McLaren \& Michie (1954) following egg transfer to the uterus was, as they suspected, associated with the pressure of the fluid medium in which the eggs were injected, and is not typical of normal pregnancy.

The correlation between the volume of inoculum and the success of egg transfers to the oviduct may be due to the back-flow of eggs into the periovarian space when the inoculum is large, or it may be related to the distance along the oviduct that the eggs were flushed at the time of transfer. The larger the volume injected, the further along the oviduct would one expect the eggs to be immediately after transfer, and the earlier the eggs might reach the uterus. In rabbits, the muscular activity of the uterus just after ovulation expels most of the eggs transferred to it on the 1st day of pseudopregnancy. Even on the 2nd and 3 rd day of pseudopregnancy, the uterine environment is toxic to the eggs, and only a small proportion of eggs develop into young if transferred to the uterus (Chang, 1950).

Within the range tested (two to ten eggs per oviduct), the percentage of transferred eggs developing to foetuses was independent of the number injected. Most of the autopsies were carried out on the 10th day p.c., before foetal mortality due to crowding would be expected to occur (McLaren \& Michie, 1959). However, with the larger numbers of eggs transferred, all the implanted foetuses would be unlikely to survive to term.

The exposure time of eggs to pronase proved critical. When the zona was completely dissolved by the pronase solution, exposing the eggs to the full concentration of the enzyme, none of the zona-free blastocysts developed into live foetuses after transfer to oviducts of recipients on the 1st day p.c. A very slightly decreased exposure time permitted development of most of the blastocysts 
(Tables 5 and 6). The deleterious effects of pronase on mouse eggs have been noted previously. McLaren (1969), using untreated pronase, found that there was a large and highly significant reduction in the total number of implantation sites, when blastocysts were transferred to the uteri of recipients following removal of the zona with pronase. Mintz (1967) suggested incubation and dialysis of pronase solution to diminish its toxicity, a recommendation which was followed in the present experiments.

Confirmatory evidence that blastocysts do not require a zona pellucida for successful transit through the oviduct is provided by the histological observations. Most of the untreated blastocysts spontaneously lost the zona pellucida within a day after transfer to the oviduct, when they were midway from the infundibulum to the uterus, yet they were no less capable of completing the transit through the oviduct and developing into foetuses than were earlier stages which retained the zona throughout their sojourn in the oviduct. Tarkowski (1961) also observed that zona-free blastocysts (single or fused) were able to traverse the oviduct and implant successfully in the uterus.

In striking contrast is the fate of zona-free eight-cell eggs. Even when the reduced time of exposure to pronase was used, such eggs transferred to oviducts of recipients on the 1st day p.c. very seldom developed into foetuses. This could not be accounted for on the basis of pronase toxicity, because $80 \%$ of eight-cell eggs from the same donor, treated with pronase for the same length of time, reached the blastocyst stage when placed into culture. Such blastocysts, cultured zona-free from the eight-cell stage, may be transferred to the uteri of pseudopregnant females, with subsequent normal development (Tarkowski, 1961; Mintz, 1965). The same situation probably prevails in the rabbit since, in this species, Moore, Adams \& Rowson (1968) were unable to recover zona-free blastomeres from the two- and four-cell stage after transfer to the oviduct.

Thus, the zona pellucida appears to be necessary for the successful transit of cleavage-stage eggs through the oviduct, while not necessary for the transit of blastocysts. Electron micrographs of rat eggs reveal intercellular connections between the trophoblast cells of blastocysts (Schlafke \& Enders, 1967). These junctional complexes, absent in eight-cell eggs, increase the stability of the bond between the cells and may prevent their disaggregation on transit through the oviduct. Eggs in culture remain relatively still, diminishing the chances of disaggregation of blastomeres once the zona is removed. On the other hand, eggs within the oviduct are transported by peristalsis to the uterus. The zona pellucida and the fluid in the perivitelline space may therefore act as a shock absorber, preventing the separation of blastomeres from the cleaving egg.

\section{NOTE ADDED IN PROOF}

The paper of Modliñski (1970) came to our attention after the present paper had been prepared. Modlinski's findings are similar to our own, with the exception that blastocysts transferred to the oviduct showed a somewhat lower percentage of successful development than did earlier stages. In addition, histological observations showed that zona-free one- and two-cell 
eggs adhered to the epithelium of the oviduct within a few hours of transfer, and did not undergo any further cleavage.

Modissski, J. (1970) The role of the zona pellucida in the development of mouse eggs in vivo. $\mathcal{J}$. Embryol. exp. Morph. (in press).

\section{ACKNOWLEDGMENT}

We are grateful for financial support from the Ford Foundation (A.M.) and the National Institutes of Health (R.A.B.; Grant No. 5T01 GMO 1777).

\section{REFERENCES}

BRINSTER, R. L. (1963) A method for in vitro cultivation of mouse ova from two-cell to blastocyst. Expl Cell Res. 32, 205.

Chang, M. C. (1950) Development and fate of transferred rabbit ova or blastocysts in relation to the ovulation time of recipients. F. exp. Zool. 114, 197.

MaLaren, A. (1969) Transfer of zona-free mouse eggs to uterine foster-mothers. F. Reprod. Fert. 19, 341 .

MaLaren, A. \& Michie, D. (1954) Transmigration of unborn mice. Nature, Lond. 174, 844.

MaLaren, A. \& Mrchie, D. (1956) Studies on the transfer of fertilized mouse eggs to uterine fostermothers. I. Factors affecting the implantation and survival of native and transferred eggs. $\mathcal{F}$. exp. Biol. 33, 394.

McLaren, A. \& Michie, D. (1959) Superpregnancy in the mouse. I. Implantation and foetal mortality after induced superovulation in females of various ages. F. exp. Biol. 36, 281.

Mintz, B. (1962) Experimental study of the developing mammalian egg: Removal of the zona pellucida. Science, N.Y. 138, 594.

Mintz, B. (1965) Genetic mosaicism in adult mice of quadriparental lineage. Science, $\mathcal{N}, Y .148,1232$.

Mintz, B. (1967) Mammalian embryo culture. In: Methods in Developmental Biology. Eds. F. H. Wilt and N. K. Wessells. Cromwell, New York.

Moore, N. W., Adams, C. E. \& Rowson, L. E. A. (1968) Developmental potential of single blastomeres of the rabbit egg. 7. Reprod. Fert. 17, 527.

Noyes, R. W. \& Dickmann, Z. (1961) Survival of ova transferred into the oviduct of the rat. Fert. Steril. $12,67$.

Orsini, M. W. \& McLaren, A. (1967) Loss of the zona pellucida in mice, and the effect of tubal ligation and ovariectomy. F. Reprod. Fert. 13, 485.

RunNer, M. N. (1951) Differentiation of intrinsic and maternal factors governing intrauterine survival of mammalian young. F. exp. Zool. 116, 1.

SCHLAfKe, S. \& Enders, A. C. (1967) Cytological changes during cleavage and blastocyst formation in the rat. F. Anat. 102, 13.

TARkowski, A. K. (1959) Experiments on the transplantation of ova in mice. Acta theriol. 2, 251.

TARkowski, A. K. (1961) Mouse chimaeras developed from fused eggs. Nature, Lond. 190, 857.

Tarkowski, A. K. (1970) Development of single blastomeres. In: Methods in Mammalian Embryology. Ed. J. C. Daniel. Freeman, San Francisco (In press). 